\author{
Marcin BUDZYŃSKI, Kazimierz JAMROZ, Łukasz JELIŃSKI, Anna GOBIS \\ Gdańsk University of Technology (Politechnika Gdańska)
}

\title{
THE EFFECTS OF ROADSIDE HAZARDS ON ROAD ACCIDENT SEVERITY
}

\section{Wpływ źródeł zagrożeń w otoczeniu dróg na ciężkość wypadków drogowych}

\begin{abstract}
The risk of becoming involved in an accident emerges when elements of the transport system do not operate properly (man - vehicle - road-roadside). The road, its traffic layout and safety equipment have a critical impact on road user safety. This gives infrastructural work a priority in road safety strategies and programmes. Run-off-road accidents continue to be one of the biggest problems of road safety with consequences including vehicle roll-over or hitting a roadside object. This type of incident represents more than 20\% of rural accidents and about $18 \%$ of all road deaths in Poland. Mathematical models must be developed to determine how selected roadside factors affect road safety and provide a basis for new roadside design rules and guidelines.
\end{abstract}

Keywords: road safety, roadside, hazards

Streszczenie: Ryzyko uwiktania w wypadek uzytkownika drogi wynika z nieprawidłowego funkcjonowania poszczególnych elementów systemu transportu drogowego (człowiek pojazd-droga-otoczenie). Droga i jej wyposażenie w środki organizacji ruchu i urzadzenia bezpieczeństwa ruchu istotnie wpływają na bezpieczeństwo jego uczestników. Działania infrastrukturalne zajmuja $w$ zwiazku $z$ tym istotne miejsce $w$ strategiach poprawy bezpieczeństwa ruchu drogowego. Wypadnięcie pojazdu z drogi jest nadal jednym z powazniejszych problemów. Skutkiem tego zdarzenia często jest wywrócenie pojazdu lub uderzenie w obiekt znajdujacy się w pobliżu drogi. Tego rodzaju zdarzenia stanowia ponad 20\% ogótu wypadków na drogach zamiejskich i sa przyczyna 18\% ogótu ofiar śmiertelnych wypadków drogowych w Polsce. Konieczna jest budowa modeli matematycznych pozwalajacych określić wplyw wybranych czynników związanych z otoczeniem dróg na miary bezpieczeństwa ruchu drogowego, co pozwoli na opracowanie zasad $i$ wytycznych projektowania otoczenia drogi.

Słowa kluczowe: bezpieczeństwo ruchu drogowego, otoczenie dróg, zagrożenia 


\section{Introduction}

Transport systems are designed and used for an efficient and safe movement of people, goods and services. Despite that there are many hazards which interfere with the systems or damage them. Hazards such as extreme weather, terrorist threats, landslides or earthquakes are difficult to predict, manage or mitigate. Transport systems are also at risk of transport accidents which have a significant impact on transport operation and user safety. As the role of transport grows, it is increasingly important to study such hazards so that they can be identified, assessed, classified and prevented [1].

Road transport accidents are random events and can be assessed for their probability. The causes may be related to the system in the broad sense, comprising man - road - vehicle - roadside $[2,3,4]$. Road infrastructure safety fits in with technical safety, a broader term which can be defined as a state free from (unacceptable) risk of consequences for people, property or the environment [5].

Safety as a term also involves terms such as hazard and risk. A hazard can be defined as the possibility of an undesired event (such as a transport accident) whose consequences will inflict damage (to property, the environment, injuries, fatalities). The simplest definition of risk is the probability of a specific consequence occurring when exposed to a hazard [6]. It is important to distinguish between risk and hazard because while both terms are often considered identical, they are in fact significantly different [7]. Risk looks at a predicted consequence while hazard means the cause of a predicted consequence [8].

Today road traffic injuries are the ninth biggest cause of death in all age groups worldwide. It is estimated that until 2030 they will become the seventh most common cause of death [9]. Developed economies have successfully challenged the relation between growing motorization and road traffic deaths. As an example, following its critical year of 1991 with nearly 8,000 people killed in road accidents, Poland has now reached a level of about 3,000 fatalities annually. Sadly, recent years have seen a slower downward trend despite the country's extensive road safety efforts. Poland's Road Fatality Rate (RFR) at 80 fatalities per 1 million population is nearly three times that of the United Kingdom or Sweden. Poland's road infrastructure continues to fail on road safety standards. With no proper solutions to address the problem, the result is the risk of road accidents, especially serious injury and fatal accidents [10]. 


\section{Problem description}

A run-off-road collision describes the primary dangerous road event in which a vehicle leaves the roadway as a result of loss of stability or sudden change of direction of travel (forced by speeding, loss of traction, etc.). Although occasionally after such collisions vehicles can return to the roadway, it very often leads to dangerous secondary events such as: roll-over, driving into a ditch, hitting an embankment or an object or roadside device e.g.: running into a road barrier, hitting a tree, a pole or a road sign [11].

There are many studies which point to roadside and its effects on road safety, especially in the context of accident severity. The most frequent factors include: presence of hard shoulders, width of safety zone, use of safety barriers and other road restraint systems (crash terminals, crash cushions), roadside obstacles (e.g. trees, utility poles, signs, land development elements, structural supports, culverts), embankments and drainage ditches. It is important to note that while none of these factors are a direct cause of a dangerous incident (running off the road), they do determine its consequences.

While hard shoulders are mostly found to reduce accident consequences, when they are too wide, they may in fact contribute to higher speeds and dangerous behaviour (as can also be seen on Polish roads) $[12,13,14]$.

Safety Zone or Clear Zone is part of a design and operation philosophy designed to meet the requirements of a self-explaining and forgiving road infrastructure $[15,16]$. The results of studies are consistent, the wider the clear zone, the milder the consequences of run-off-road accidents $[17,18]$.

Studies of the effects of roadside safety barriers and obstacles show that dangerous incidents are more frequent where these elements are provided more intensely. However, barriers as such clearly help to reduce the consequences when they protect against obstacles such as trees, utility poles and other "hard" roadside elements $[19,20,21]$.

\section{Effects of the roadside on road safety}

The following types of roadside accidents were selected (from SEWIK, a police database): hitting a tree, hitting a barrier, hitting a utility pole or sign, vehicle rollover on the shoulder, vehicle roll-over down an embankment and into a ditch.

Between 2012-2016 there were 17,400 accidents involving the roadside (10\% of all road accidents in that period) with 22,000 injuries (10\%), including serious injuries at 7,100 (12\%) and 3,000 fatalities (18.5\%). Fig. 1 shows the percentage 
change in fatalities by accident type in the years 2007-2016. A comparison of 2007 and 2016 data shows that accidents involving hitting a pedestrian are down (from $34 \%$ to $28 \%$ ), side crashes are up (from $14 \%$ to $19 \%$ ) and run-off-road accidents are slightly down (from $20 \%$ to $18.5 \%$ ).

The severity of roadside accidents goes against the idea of "forgiving" roads and the Vision Zero Programme [22] which made it very clear that the objective of road transport measures should be to ensure road user safety.

Fig. 2 shows accident severity by accident type. It is evident that just as headon collisions, run-off-road accidents are the most severe where severity is expressed as the number of fatalities per 100 accidents. Serious injuries are also high. Runoff-road accidents claim 17 deaths per 100 accidents, which is double the figure of the other types of accidents combined. These accidents are so severe because they involve the vehicle crashing into a hard obstacle (tree, utility pole, bridge support, culvert front wall, barrier).

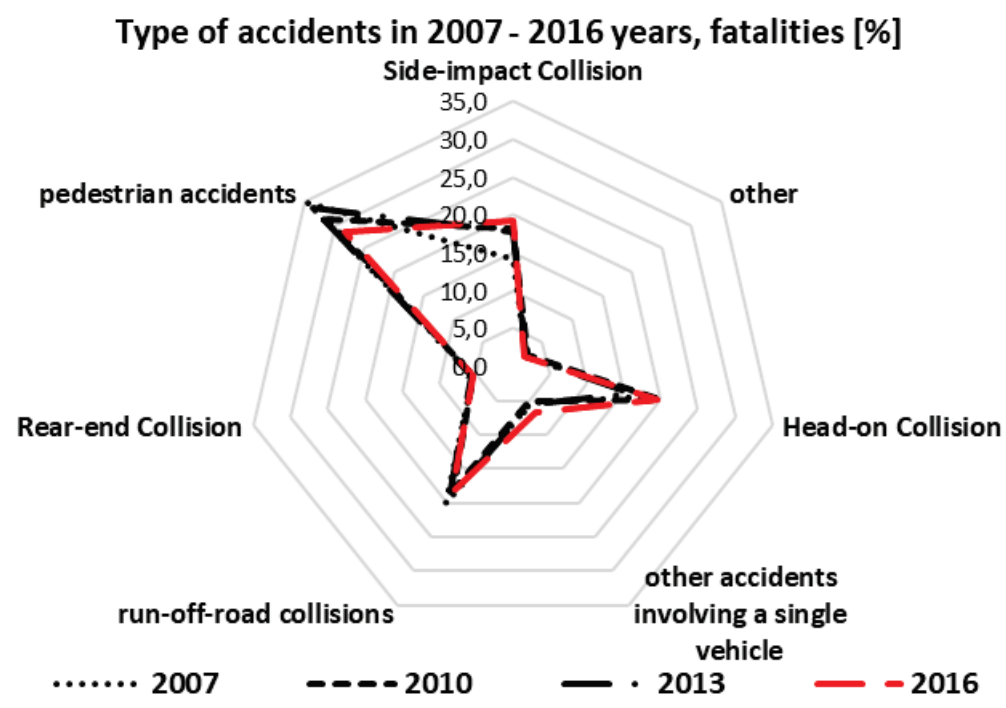

Fig. 1. Percentage of fatalities by accident type

Analysis of statistics shows that trees are the primary source of roadside hazard in Poland. It is particularly acute on roads in the north-west region where many roads are lined up with trees. Figures $3 a$ (entire road network) and $3 b$ (rural roads) show the percentage of run-off-road fatalities in overall fatalities. 


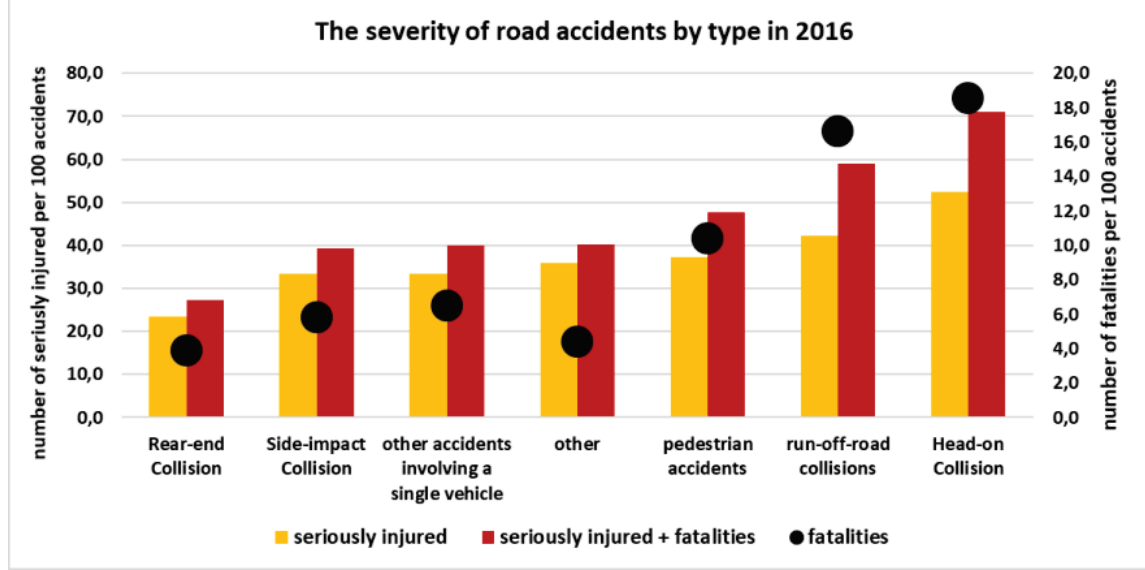

Fig. 2. Accident severity by accident type

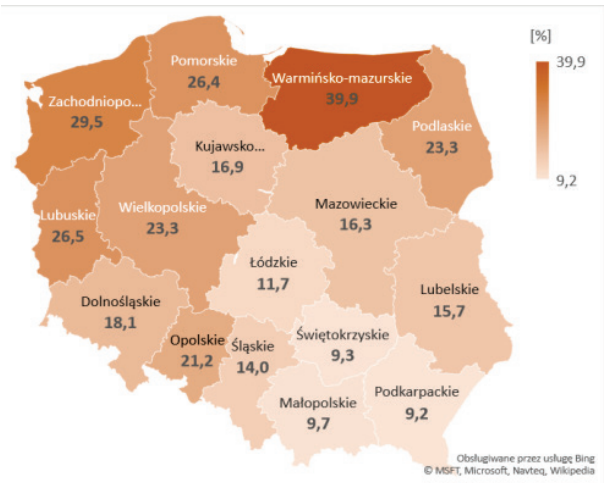

a) entire road network

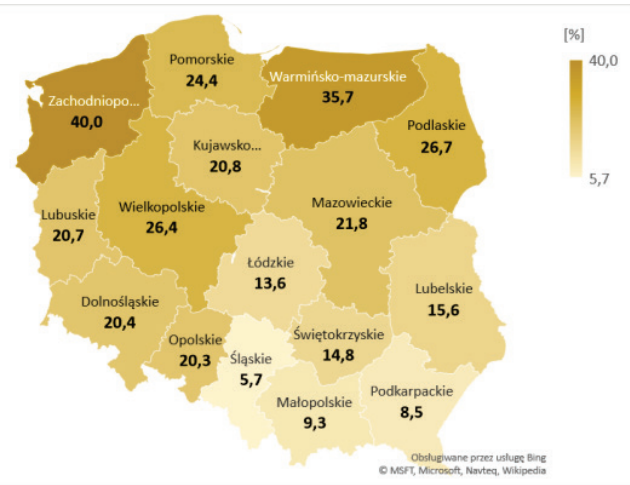

b) rural roads

Fig. 3. The percentage of run-off-road fatalities in overall fatalities

\section{Identifying roadside hazards}

Results of road infrastructure safety inspections conducted on-site helped to identify a number of sources of roadside hazards [23]. There is photographic documentation of selected sources of hazards (fig. 4). The most frequent sources of roadside hazards include:

- trees along road edge (up to 3.5 meters away from road edge),

- other greenery restricting visibility,

- steep embankments - fig. 4a,

- elements of infrastructure which are unyielding - fig. 4b, 
- wrong properties and parameters of safety barriers - fig. 4c,

- unsecured supports of civil engineering objects - fig. $4 \mathrm{~d}$,

- drainage facilities - front walls of culverts,

- poor technical condition of shoulders.

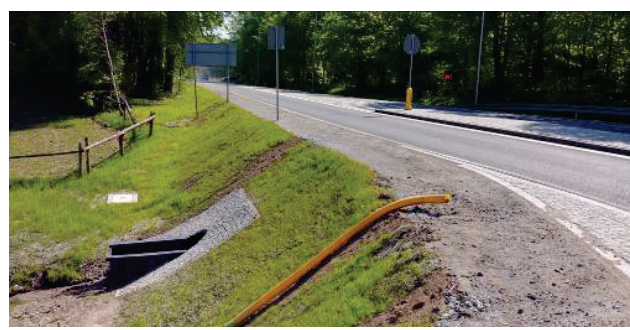

a)

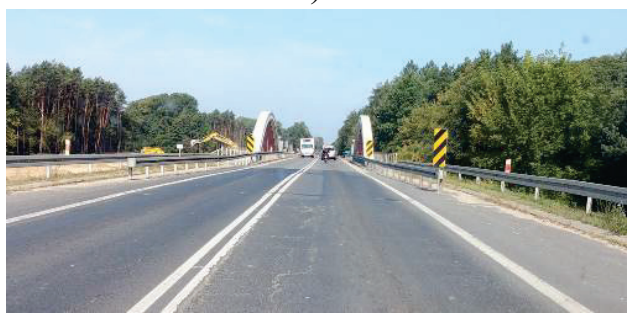

c)

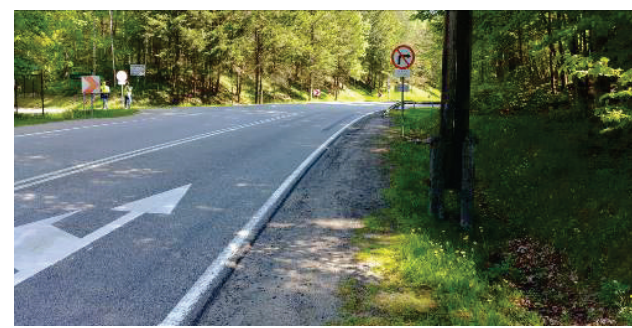

b)

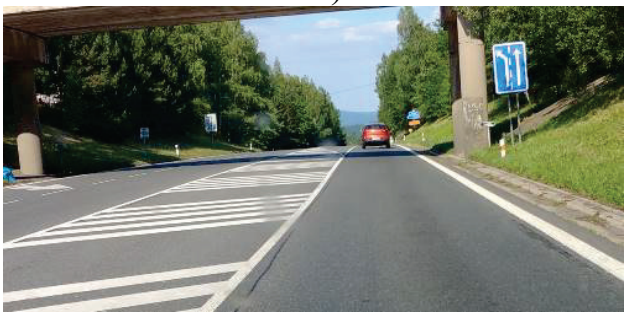

d)

Fig. 4. Examples of sources of roadside hazards

\section{Modelling the effects of the roadside on accident severity}

\subsection{Preliminary work}

The work was conducted on national roads in the region of Pomorskie. The study process was divided into three phases. The first phase involved field work and building an inventory of road parameters including the identification of roadside hazards. Phase two was designed to build a database to bring together road parameters, traffic and road accident data. In the last stage mathematical models were built to define the correlations between roadside parameters and the number of accident victims. The analyses were made using data from the police database SEWIK (2014-2016).

The inventory covered sections of national roads at the total length of about 777 $\mathrm{km}$ (except national roads in cities). There were separate inventories for the left and right edge of the roadway and the central reservation. Potential roadside hazards were identified: trees close to the road (up to $3.5 \mathrm{~m}$ from road edge), trees further 
away from the road (more than $3.5 \mathrm{~m}$ from road edge), embankments and their grades, types of barriers (concrete, steel barriers, wire rope steel barriers), width and type of shoulder. Road class was also studied.

\subsection{Building mathematical models}

Selected from a number of other models developed in the study, the model below represents road accident victim density (GOF). It is presented with equation (1). The objective of the model is to estimate road accident casualties on national roads per one kilometre of road within a specific period. The model comprises factors which are related to the risk of an accident (independent variables). They are: traffic volume on a road section $(\mathrm{Q})$, road class $(\mathrm{C})$, percentage of infrastructure and roadside elements: barriers (B), embankments (S), trees within $3.5 \mathrm{~m}$ from road edge $\left(T_{1}\right)$, trees above $3.5 \mathrm{~m}\left(T_{2}\right)$, forests $\left(T_{3}\right)$, with trees more than $3.5 \mathrm{~m}$ from road edge, hard shoulders which are more than $1.5 \mathrm{~m}$ wide $\left(\mathrm{P}_{1}\right)$, hard shoulders up to 1.5 $\mathrm{m}$ in width $\left(\mathrm{P}_{2}\right)$, unpaved shoulders $\left(\mathrm{P}_{3}\right)$, with no width specified.

The model of victim density is described with this formula (1):

$$
\left.G O F(Y)=\alpha * Q^{\beta_{1}} * e^{\left(B^{\beta_{2}}+S^{\beta_{3}}+T_{1}^{\beta_{4}}+T_{2}^{\beta_{5}}+T_{3}^{\beta_{6}}+C^{\beta_{7}}+P_{1}^{\beta_{8}}+P_{2}^{\beta_{9}}+P_{3}^{\beta_{10}}\right.}\right)
$$

where: GOF(Y) - expected number of accident victims per kilometre of road (dependent variable), $\alpha$ - adjustment coefficient, $\mathrm{Q}$ - annual average daily traffic / annual average daily traffic flow (AADT), $\beta_{\mathrm{j}}(1,2 . . \mathrm{n})$ - computation coefficient, $\mathrm{B}, \mathrm{S}, \mathrm{T}_{1}, \mathrm{~T}_{2}, \mathrm{~T}_{3}, \mathrm{C}, \mathrm{P}_{1}, \mathrm{P}_{2}, \mathrm{P}_{3}$ - factors involved in the risk of an accident (independent variables).

Coefficient data are calculated and used in the formula. Accident victim density (injuries and fatalities) on a selected road section can then be calculated. The model offers a very high determination coefficient $\left(\mathrm{R}^{2}\right)$ equal to 0.78 (which means a $78 \%$ match between the model and real data).

\subsection{Discussion of the results}

How effective road safety measures are depends largely on how extensively tools are used that help to estimate the effectiveness of the treatments. Prognostic models are one such tool. They can be used to identify hazardous sections or study the relations between potential accident consequences and the selected road section features. An analysis of Pomorskie region's results shows that victim density goes down as the number of safety barriers (fig. 5) and hard shoulders increases. It is also important to note (fig. 6) that restraint systems such as road barriers are a physical obstacle which in itself may represent a real road user hazard. As a result, 
barriers are only recommended when roadside obstacles are present which cannot be eliminated or modified (embankments, drainage ditches).

\section{Summary}

Previous work by the authors in the area of road infrastructure safety management with a special focus on the roadside helps to formulate the following conclusions:

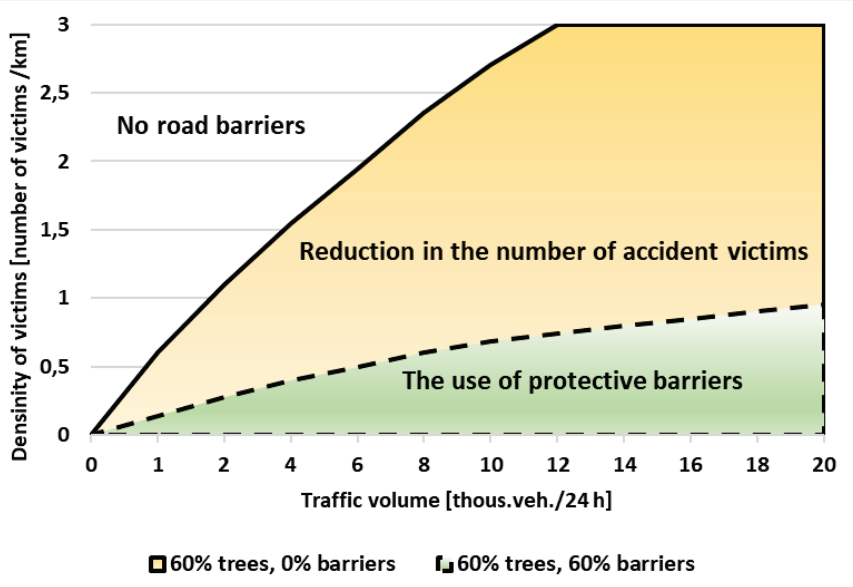

Fig. 5. Victim density GOF in relation to the distance between trees and road and provision of barriers

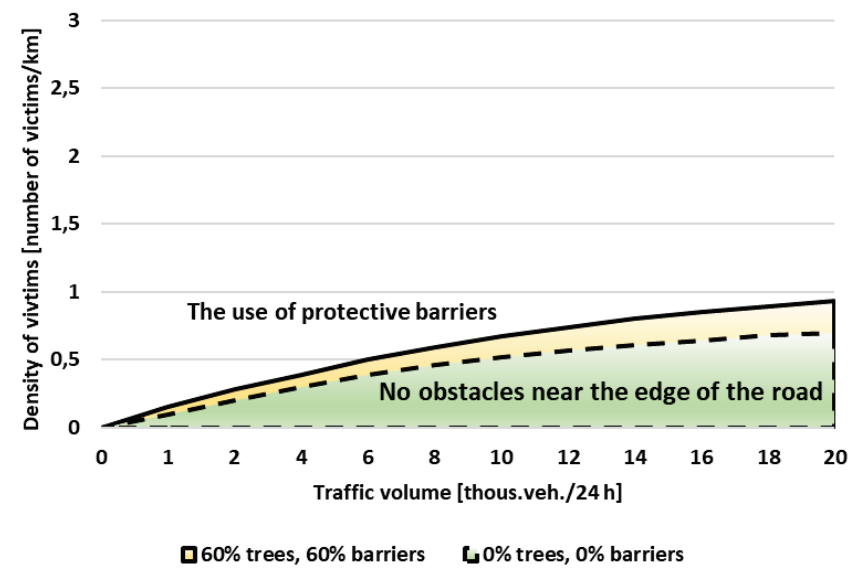

Fig. 6. Victim density GOF in relation to the provision of safety barriers 
1. Road safety management is a very complex process and must take account of a number of unknowns and random phenomena. This is why modern tools must be used to help with identifying sources of hazards and hazards.

2. Elements of road infrastructure are some of the factors that have a strong contribution to accidents (although in percentage terms, they are outweighed by human factors - behaviour, road user error); infrastructure-related factors also have the strongest bearing on single vehicle-accident consequences (running off the road, vehicle roll-over, crashing into a roadside element).

3. Roadside-related factors dominate among infrastructure factors which are responsible for the consequences of single vehicle accidents. This is largely due to a lack of regulations. Rules must be adopted to regulate road network design and maintenance processes. Nearly $20 \%$ of all of Poland's road accident fatalities were killed in run-off-road accidents.

4. Models must be built and developed to define how specific factors change road safety measures. This should trigger a revision of road infrastructure design and maintenance regulations.

\section{References}

1. Cova T.J., Conger S.: Transportation Hazards. Transp. Eng. Handb., No. 801, 2003.

2. Treat JR et al.: Tri-Level Study of the Causes of Traffic Accidents. Res. Rep. Compil. by Inst. Res. Public Saf. to US Separtment Transp. Washingt. DC, 1979.

3. Vogel L., Bester C.J.: A relationship between accident types and causes. Proc. 24th South. African Transp. Conf., 2005.

4. PIARC: Road accident investigation guidelines for road engineers. 2007.

5. The Institution of Engineering and Technology: Glossary of Safety Terminology. No. $00,2017$.

6. Jamroz K.: Method of risk management in road engineering. Gdańsk University of Technology, 2011.

7. Ulbig E., Hertel R., Böl G.-F.: Evaluation of Communication on the Differences between "Risk" and "Hazard" Project implementation. 2010.

8. Lofstedt R.E.: Risk vs. Hazard how to regulate. Ejrr, Vol. 2, 2011.

9. WHO: Global Status Report on Road Safety 2015.

10. Budzyński M., Jamroz K., Jeliński Ł.: Assessment of road restraint systems in Polish conditions. Journal of KONBiN, No. 45, 2018, DOI 10.2478/jok-2018-0017.

11. Budzyński M., Jamroz K.: Strategy to reduce the number and consequences of run-offroad. Drogownictwo, Vol. 64, no. 4-5, 2009.

12. Abdel-Rahim A., Sonnen J.: Potential Safety Effects of Lane Width and Shoulder Width on Two-Lane Rural State Highways in Idaho. 2012. 
13. Hallmark T.J., Qiu S.L., Pawlovitch Y., McDonald M.: Assessing the safety impacts of paved shoulders. J. Transp. Saf. Secur., 2013.

14. Zegeer C.V, Council F.M.: Safety relationships associated with cross-sectional roadway elements. Transp. Res. Rec., 1995.

15. Aashto: Roadside Design Guide. 2011.

16. Saleh P., Philippe N., La Torre F., Helfert M.: A Guidance Document for the Implementation of the CEDR Forgiving Roadsides report. Natl. Roads Auth., Vol. 12, No. 16, 2013.

17. Park J., Abdel-Aty M., Lee C., Exploration and comparison of crash modification factors for multiple treatments on rural multilane roadways. Accid. Anal. Prev., Vol. 70, Sep. 2014.

18. Stamatiadis N., Pigman J., Sacksteder J., Ruff W., Lord D.: Impact of Shoulder Width and Median Width on Safety. NCHRP Rep. 633, 2009.

19. Jurewicz C., Pyta V.: Effect of clear zone widths on run-off-road crash outcomes. Australas. Road Saf. Res. Polic. Educ. Conf., No. September, 2010.

20. Van Petegem J.W.H., Wegman F.: Analyzing road design risk factors for run-off-road crashes in the Netherlands with crash prediction models. J. Safety Res., Vol. 49, no. February, 2014.

21. Park J., Abdel-Aty M., Assessing the safety effects of multiple roadside treatments using parametric and nonparametric approaches. Accid. Anal. Prev., Vol. 83, Oct. 2015.

22. Tingvall C., Haworth N.: Vision Zero-An ethical approach to safety and mobility. In: 6th ITE International Confer ence Road Safety \& Traffic Enforcement: Beyond 2000, Melbourne, 6-7 September 1999, 2000,

23. Budzyński M., Jamroz K., Kustra W.: Road safety inspection as a tool for road safety management-the polish experience. Journal of KONBiN, No. 42, 2017, DOI 10.1515/jok-2017-0017. 


\section{WPLYW ŹRÓDEŁ ZAGROŻEŃ W OTOCZENIU DRÓG NA CIĘŻKOŚĆ WYPADKÓW DROGOWYCH}

\section{Wprowadzenie}

Systemy transportowe są zaprojektowane i użytkowane tak, aby efektywnie i bezpiecznie przemieszczać ludzi, towary i usługi. Pomimo to wiele zagrożeń zakłóca lub uszkadza te systemy. Zagrożenia takie jak ekstremalne warunki pogodowe, terroryzm, osunięcia ziemi czy trzęsienia ziemi są trudnie do przewidzenia, zarządzania i łagodzenia. Do zagrożeń systemów transportowych należą również wypadki, a ich wpływ na funkcjonowanie transportu i bezpieczeństwo użytkowników jest znaczny. Systematyczne badanie zagrożeń w zakresie ich identyfikacji, oceny, klasyfikacji i sposobów przeciwdziałania nabiera coraz większego znaczenia, wraz ze wzrostem roli transportu [1].

Transport drogowy jest najbardziej niebezpieczny z punktu widzenia liczby ofiar śmiertelnych w przeliczeniu na liczbę pasażerów, długość podróży i czas podróży. Podróże kolejowe i lotnicze to najbezpieczniejsze rodzaje transportu w stosunku do przebytej odległości. Zagrożenie życia w przeliczeniu na czas podróży jest najniższe w przypadku podróży pociąiem, a następnie w kolejności są podróże wodne i lotnicze. Zagrożenie życia związane z podróżami wodnymi jest od 4 do 8 razy większe niż w przypadku podróży pociagiem [2].

Wypadki w transporcie drogowym są związane ze zdarzeniami losowymi, których prawdopodobieństwo można szacować, zaś ich przyczyny mogą być związane z szeroko pojętym systemem: człowiek - droga - pojazd - otoczenie [3, 4]. Bezpieczeństwo infrastruktury drogowej wpisuje się $\mathrm{W}$ szerokie pojęcie bezpieczeństwa technicznego, które można zdefiniować jako stan wolny od ryzyka (niedopuszczalnego) wystapienia szkód dla osób, majątku lub środowiska [5].

$Z$ pojęciem bezpieczeństwa związane są zagrożenie i ryzyko. Zagrożenie można zdefiniować jako możliwość wystąpienia zjawiska niepożądanego (np. wypadek transportowy), które będzie miało konsekwencje w postaci szkody (straty materialne, środowiskowe, ranni, ofiary śmiertelne). Najprostsza definicja ryzyka to prawdopodobieństwo wystąpienia szkody określonej wielkości w wyniku narażenia na zagrożenie [6]. Należy podkreślić konieczność rozróżnienia ryzyka i zagrożenia, ponieważ często te pojęcia są utożsamiane i używane wymiennie, podczas gdy występują między nimi zasadnicze różnice [7]. Ryzyko wskazuje na 
przewidywaną szkodę, podczas gdy zagrożenie oznacza przewidywaną przyczynę szkody [8].

Obrażenia poniesione w wyniku wypadków drogowych są jedną z głównych przyczyn zgonów na świecie. Ponad 1,4 miliona ludzi ginie każdego roku na drogach na całym świecie, a ok. 50 milionów odnosi obrażenia, co często skutkuje dalszym życiem z długofalowymi negatywnymi konsekwencjami zdrowotnymi. $\mathrm{Na}$ całym świecie wypadki drogowe są główną przyczyną śmierci wśród osób w wieku 15-29 lat. Obrażenia związane z ruchem drogowym są obecnie dziewiątą największą przyczyną śmierci we wszystkich grupach wiekowych na świecie. Przewiduje się, że do roku 2030 stanie się to siódma główna przyczyna śmierci [9]. W gospodarkach rozwiniętych, zdołano przełamać związek między rosnącą motoryzacją i liczbą ofiar śmiertelnych w ruchu drogowym, a w części z nich osiągnięto w tym zakresie znaczące sukcesy. Przykładem może być Polska, która po krytycznym roku 1991, kiedy zarejestrowano blisko 8 tys. ofiar śmiertelnych wypadków drogowych, obecnie notuje ok. 3 tys. ofiar śmiertelnych wypadków rocznie. Niestety negatywnym aspektem jest ograniczenie trendu spadkowego $\mathrm{w}$ ostatnich latach i brak znaczącej poprawy, pomimo wielu prowadzonych w naszym kraju działań w zakresie poprawy bezpieczeństwa użytkowników dróg. Wskaźnik ofiarochłonności demograficznej (ODZ) na poziomie 80 ofiar śmiertelnych na 1 mln mieszkańców, w naszym kraju jest blisko trzykrotnie wyższy niż w Wielkiej Brytanii czy Szwecji. W dalszym ciagu infrastruktura drogowa w Polsce odbiega w wielu przypadkach od wymaganych standardów bezpieczeństwa. Brak poprawnych rozwiązań skutkuje ryzykiem wystapienia wypadków drogowych, szczególnie wypadków poważnych z konsekwencjami w postaci wystąpienia ofiar śmiertelnych i ciężko rannych [10].

\section{Opis problemu}

Pod pojęciem wypadnięcia $\mathrm{z}$ drogi rozumie się takie pierwotne zdarzenie niebezpieczne, w którym pojazd wypada $\mathrm{z}$ jezdni drogi w wyniku utraty stateczności lub nagłej zmiany kierunku jazdy (wymuszonej jazdą ze zbyt dużą prędkością, utratą przyczepności koła do nawierzchni itp.). W wyniku tego zdarzenia niekiedy następuje powrót pojazdu na jezdnię, ale bardzo często występuje wtórne zdarzenie niebezpieczne polegające na: wywróceniu się pojazdu, wjechaniu pojazdu do rowu, uderzenie w skarpę lub uderzenie w urządzenie czy obiekt zlokalizowany $\mathrm{w}$ pasie drogowym albo jego bliskim otoczeniu, np.: najechanie pojazdu na barierę drogową, drzewo, słup lub znak drogowy [11]. 
W wielu pracach wskazuje się wpływ cech otoczenia drogi na poziom bezpieczeństwa ruchu drogowego, głównie w zakresie ciężkości wypadków. Do czynników najczęściej wymienianych należą: występowanie pobocza utwardzonego, szerokość strefy bezpieczeństwa, stosowanie barier ochronnych i innych urządzeń powstrzymujących pojazd przed wypadnięciem (terminale zderzeniowe, osłony energochłonne), przeszkody w otoczeniu dróg (np. drzewa, słupy, znaki, elementy uzbrojenia terenu, podpory obiektów, przepusty), kształtowanie skarp i rowów odwadniających. Należy podkreślić, że wszystkie $\mathrm{z}$ wymienionych powyżej czynników nie są zazwyczaj bezpośrednią przyczyną zdarzenia niebezpiecznego (wypadnięcie pojazdu z jezdni), ale decydują o konsekwencjach tego zdarzenia.

Występowanie pobocza utwardzonego to $\mathrm{w}$ większości zidentyfikowanych badań pozytywny wpływ na zmniejszenie konsekwencji wypadków, może jednak występować przy zbyt dużych szerokościach zjawisko zwiększania prędkości i występowanie niebezpiecznych zachowań (obserwowane również na polskich drogach) $[12,13,14]$.

Strefa bezpieczeństwa (strefy wolnej od przeszkód, z ang. clean zone lub safety zone) to element związany z filozofią podejścia do projektowania i eksploatowania infrastruktury drogowej zgodnie z wymaganiami dla drogi „samowyjaśniającej się” i „wybaczającej błędy” kierowców $[15,16]$. Wyniki prac są zgodne - im szersza jest strefa wolna od przeszkód, tym łagodniejsze są skutki wypadków drogowych związanych z wypadnięciem z jezdni [17, 18].

Wyniki badań dotyczących wpływu występowania barier ochronnych oraz przeszkód w otoczeniu dróg, wskazują na zwiększenie częstości zdarzeń niebezpiecznych przy zwiększonej obecności tych elementów. Jednocześnie obecność barier zdecydowanie zmniejsza skutki tych zdarzeń w przypadku ochrony przeszkód typu drzewa, słupy lub inne twarde elementy w otoczeniu [19, 20, 21].

\section{Wpływ otoczenia drogi na bezpieczeństwo ruchu drogowego}

Do wypadków związanych bezpośrednio $\mathrm{z}$ otoczeniem drogi wybrano następujące ich rodzaje (na podstawie policyjnej bazy danych SEWIK): najechanie na drzewo, najechanie na barierę, najechanie na słup lub znak, wywrócenie pojazdu na poboczu, wywrócenie pojazdu na skarpie, w rowie.

W latach 2012-2016 zarejestrowano 17,4 tys. wypadków związanych $\mathrm{z}$ otoczeniem dróg ( $10 \%$ wszystkich wypadków drogowych $\mathrm{w}$ tym okresie). Skutkiem tych wypadków było 22 tys. rannych $(10 \%)$, w tym ciężko rannych 7,1 tys. osób (12\%) oraz 3 tys. ofiar śmiertelnych (18,5\%). Na rys. 1 przedstawiono 
zmianę procentową udziału ofiar śmiertelnych $\mathrm{w}$ poszczególnych rodzajach wypadków w latach 2007-2016. Porównując dane dla lat 2007 i 2016 zwraca uwagę spadek wartości dla wypadków związanych $\mathrm{z}$ najechaniem na pieszego (z 34\% do 28\%), wzrost dla zderzeń bocznych (z 14\% do 19\%) oraz niewielki spadek w przypadku wypadnięcia (z 20\% do $18,5 \%$ ).

Tak poważne skutki wypadków związanych z otoczeniem stanowią zaprzeczenie idei dróg „wybaczających błędy” oraz programu „Wizja Zero” [22], który bardzo wyraźnie wskazał, że głównym celem wszystkich działań w zakresie transportu drogowego powinno być bezpieczeństwo użytkownika.

Na rys. 2 przedstawiono ciężkość wypadków drogowych według rodzajów. Zwraca uwage, że wypadnięcie z drogi, obok zderzeń czołowych, charakteryzuje się zdecydowanie największą ciężkością, liczoną liczbą ofiar śmiertelnych na 100 wypadków, ale również znaczną ciężkością liczoną liczbą ofiar ciężko rannych. Wypadnięcia pojazdu z drogi są przyczyną 17 ofiar śmiertelnych na 100 wypadków, co jest dwukrotnie większą wartością niż w przypadku pozostałych wypadków branych pod uwagę łącznie. Tak wysoka ciężkość jest efektem uderzenia pojazdu $\mathrm{w}$ przeszkodę trwałą (drzewo, słup, podpora obiektu mostowego, ścianka czołowa przepustu, bariera).

Analiza danych statystycznych wskazuje, że w Polsce głównym źródłem zagrożenia w otoczeniu dróg są drzewa. Szczególnie duże zagrożenie występuje na drogach położonych w północno-zachodniej części kraju, gdzie wzdłuż dróg pozostało wiele alei drzew. Na rysunkach 3a (cała sieć drogowa) i 3b (drogi zamiejskie) przedstawiono udział procentowy ofiar śmiertelnych $\mathrm{w}$ wyniku wypadnięć z jezdni w stosunku do wszystkich ofiar śmiertelnych.

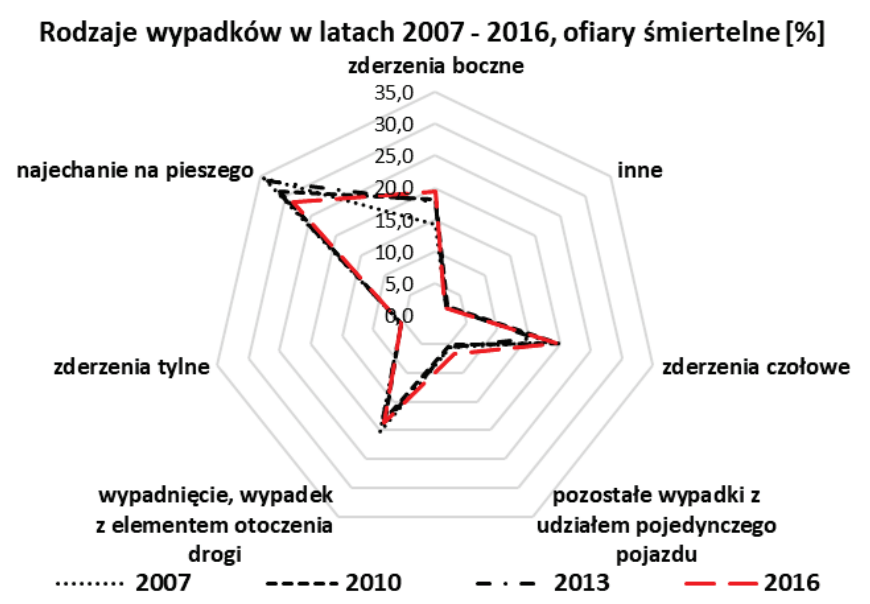

Rys. 1. Udział procentowy ofiar śmiertelnych wg rodzajów wypadków 


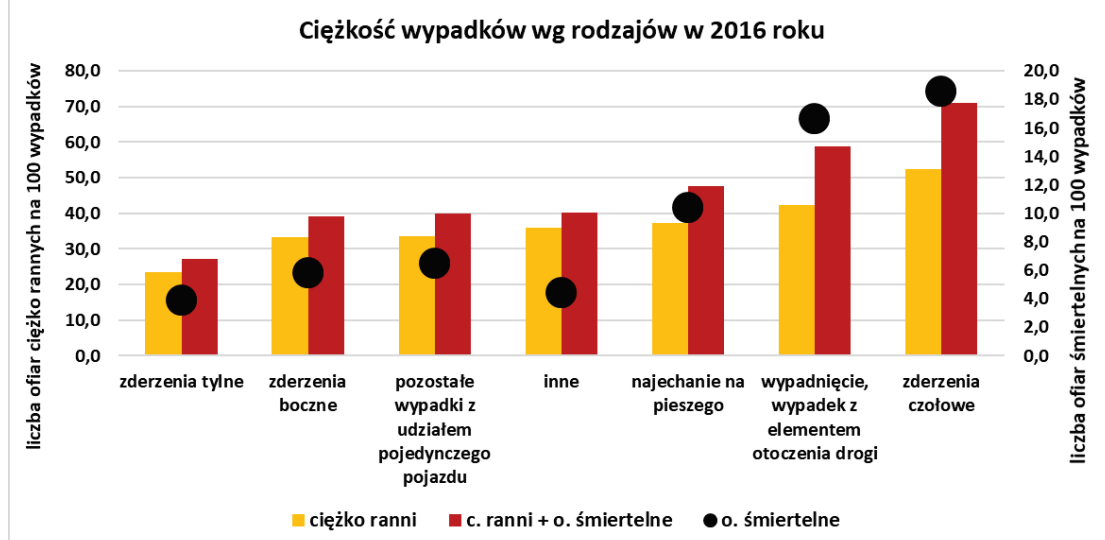

Rys. 2. Ciężkość wypadków drogowych wg rodzajów

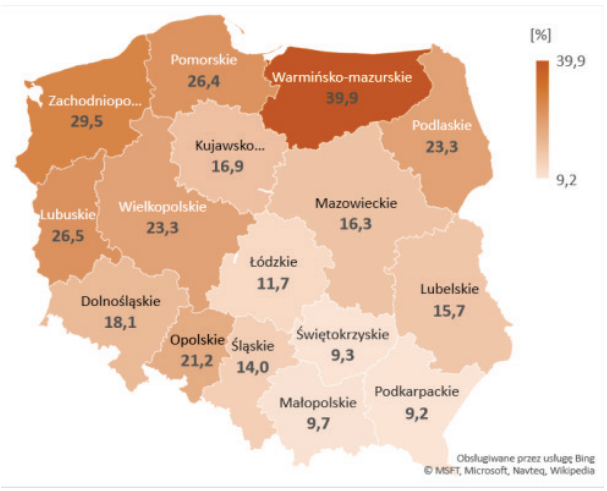

a) cała sieć drogowa

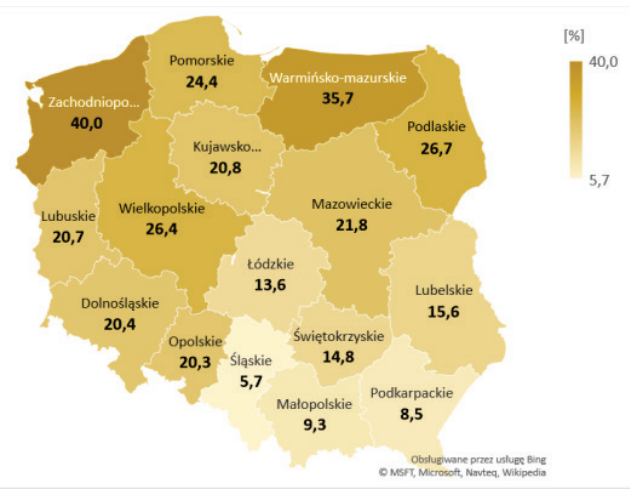

b) drogi zamiejskie

Rys. 3. Udział procentowy ofiar śmiertelnych w wyniku wypadnięć z drogi

\section{Identyfikacja zagrożeń w otoczeniu dróg}

$\mathrm{Na}$ podstawie licznych badań terenowych, związanych $\mathrm{z}$ inspekcją infrastruktury drogowej pod kątem bezpieczeństwa, zidentyfikowano szereg źródeł zagrożeń w otoczeniu dróg [23]. Wybrane źródła zagrożeń zilustrowano dokumentacją fotograficzną (rys. 4). Do źródeł zagrożeń najczęściej występujących w otoczeniu dróg należą:

- drzewa przy krawędzi jezdni (w odl. do 3,5 metrów od krawędzi jezdni),

- inna zieleń ograniczająca widoczność,

- zbyt strome pochylenia skarp - rys. $4 a$, 
- elementy uzbrojenia terenu, które nie są podatne na uderzenie - rys. 4b,

- bariery drogowe o nieprawidłowych cechach i parametrach - rys. 4c,

- podpory obiektów inżynierskich, bez zabezpieczenia - rys. 4d,

- urządzenia odwodnienia - ścianki czołowe przepustów drogowych,

- zły stan techniczny poboczy.

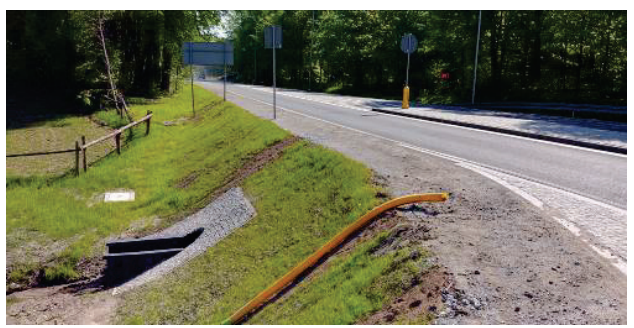

a)

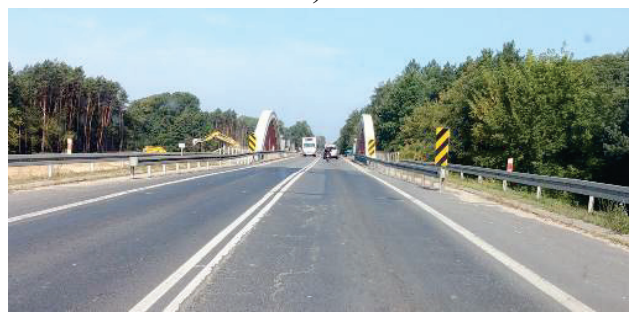

c)

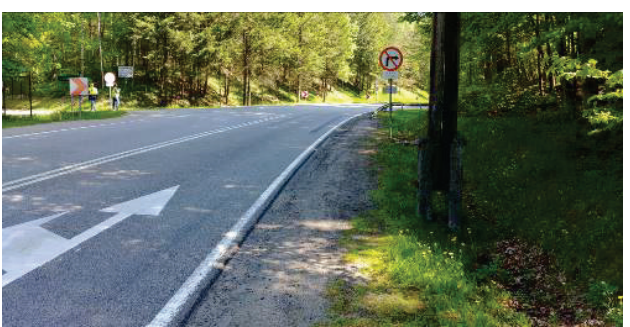

b)

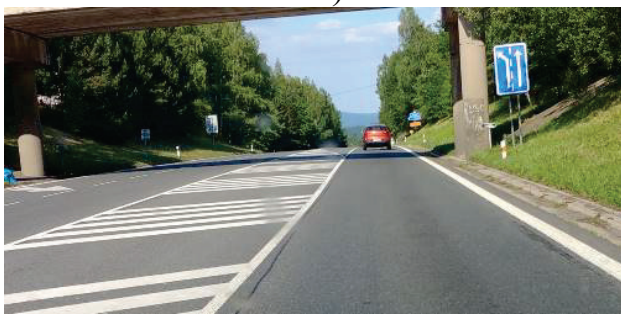

d)

Rys. 4. Przykłady źródeł zagrożeń w otoczeniu drogi

\section{Modelowanie wpływu otoczenia drogi na ciężkość wypadków drogowych}

\subsection{Prace wstępne}

Badaniami objęto sieć dróg krajowych w woj. pomorskim. Proces badawczy podzielono na trzy etapy. Pierwszy z nich to badania terenowe i inwentaryzacja parametrów drogowych, w tym identyfikacja zagrożeń w otoczeniu jezdni. Etap drugi to budowa bazy danych, łączącej dane o parametrach drogowych, czynniki ruchowe oraz zdarzenia drogowe. Ostatnim etapem była budowa modeli matematycznych określających korelacje pomiędzy parametrami otoczenia drogi a liczbą ofiar wypadków drogowych. Analizy wykonane zostały na podstawie danych pochodzących z policyjnej bazy SEWIK (lata 2014-2016). 
Inwentaryzacji poddano odcinki dróg krajowych o łącznej długości ok. 777 km (bez dróg krajowych w powiatach grodzkich). Dane zinwentaryzowano oddzielnie dla lewej oraz prawej krawędzi jezdni, a także dla pasa dzielącego. Identyfikowano potencjalne zagrożenia $\mathrm{w}$ otoczeniu jezdni: drzewa w bliskim otoczeniu drogi (do 3,5 m od krawędzi jezdni), drzewa w dalszym otoczeniu drogi (powyżej 3,5 m od krawędzi jezdni), skarpy i ich pochylenia, rodzaje barier (betonowe, stalowe o prowadnicy kształtowej, stalowe o prowadnicy linowej), szerokość i rodzaj pobocza drogowego. Dodatkowym czynnikiem była klasa drogi.

\subsection{Budowa modeli matematycznych}

$\mathrm{Z}$ wielu modeli dla miar bezpieczeństwa ruchu drogowego, które zostały zbudowane w ramach badań, poniżej przedstawiony został model dla gęstości ofiar wypadków drogowych (GOF). Postać modelu przedstawia równanie (1). Zadaniem modelu jest oszacowanie oczekiwanej liczby ofiar wypadków na drogach krajowych przypadających na kilometr drogi w określonym czasie. W skład modelu wchodzą czynniki, które wiążą się z ryzykiem wystąienia wypadku (zmienne niezależne) i są to: natężenie ruchu na odcinku drogi (Q), klasa drogi (C), udziały procentowe poszczególnych elementów infrastruktury i otoczenia drogi: barier (B), skarp (S), drzew zlokalizowanych do 3,5 m od krawędzi jezdni $\left(\mathrm{T}_{1}\right)$, drzew zlokalizowanych powyżej $3,5 \mathrm{~m}\left(\mathrm{~T}_{2}\right)$, lasów $\left(\mathrm{T}_{3}\right)$ z drzewami w odległości ponad 3,5 m od krawędzi jezdni, poboczy utwardzonych o szerokości ponad 1,5 m $\left(\mathrm{P}_{1}\right)$, poboczy utwardzonych o szerokości do $1,5 \mathrm{~m}\left(\mathrm{P}_{2}\right)$, poboczy gruntowych $\left(\mathrm{P}_{3}\right)$, bez określania ich szerokości. Model gęstości ofiar opisano następującym wzorem (1):

$$
\left.G O F(Y)=\alpha * Q^{\beta_{1}} * e^{\left(B^{\beta_{2}}+S^{\beta_{3}}+T_{1}^{\beta_{4}}+T_{2}^{\beta_{5}}+T_{3}^{\beta_{6}}+C^{\beta_{7}}+P_{1}^{\beta_{8}}+P_{2}^{\beta_{9}}+P_{3}^{\beta_{10}}\right.}\right)
$$

przy czym poszczególne oznaczenia to:

GOF(Y) - oczekiwana liczba ofiar wypadków przypadająca na kilometr drogi (zmienna zależna),

a $\quad-$ współczynnik korygujący,

Q _ - średnioroczne dobowe natężenie ruchu / annual average daily traffic flow (AADT),

$\beta_{\mathrm{j}}(1,2 . . \mathrm{n})-$ współczynniki obliczeniowe,

$\mathrm{B}, \mathrm{S}, \mathrm{T}_{1}, \mathrm{~T}_{2}, \mathrm{~T}_{3}, \mathrm{C}, \mathrm{P}_{1}, \mathrm{P}_{2}, \mathrm{P}_{3}$ - czynniki związane $\mathrm{z}$ ryzykiem wystapienia wypadku (zmienne niezależne) 
Obliczając wszystkie ze współczynników i podstawiając je do wzoru, można obliczyć gęstość ofiar wypadków (ofiar rannych i śmiertelnych), które miały miejsce na wybranym odcinku drogi. Uzyskany model cechuje się wysokim współczynnikiem determinacji $\left(\mathrm{R}^{2}\right)$ równym 0,78 (co oznacza $78 \%$ dopasowanie modelu do danych rzeczywistych).

\subsection{Dyskusja wyników}

Efektywność stosowanych środków bezpieczeństwa ruchu drogowego w dużej mierze zależy od stopnia wykorzystywania narzędzi do szacowania efektywności wprowadzanych środków. Do takich narzędzi zalicza się m.in. modele prognostyczne. Modele te można wykorzystywać m.in. do identyfikacji odcinków niebezpiecznych, czy badań zależności potencjalnych skutków zdarzeń od wybranych cech odcinka drogowego. Analizując wyniki przeprowadzonych analiz w województwie pomorskim, można zauważyć, iż gęstość ofiar maleje wraz ze wzrostem liczby barier ochronnych (rys. 5) oraz poboczy utwardzonych. Należy również zauważyć (rys. 6), że systemy powstrzymujące, takie jak bariery stosowane przy drogach, stanowią fizyczne przeszkody, których obecność może stanowić realne zagrożenie dla bezpieczeństwa uczestników ruchu drogowego. Dlatego też zaleca się stosowanie barier wyłącznie w przypadkach, gdy nie można wyeliminować przeszkód znajdujących się w pobliżu krawędzi jezdni lub inaczej ukształtować otoczenia drogi (skarpy, rowy odwadniające).

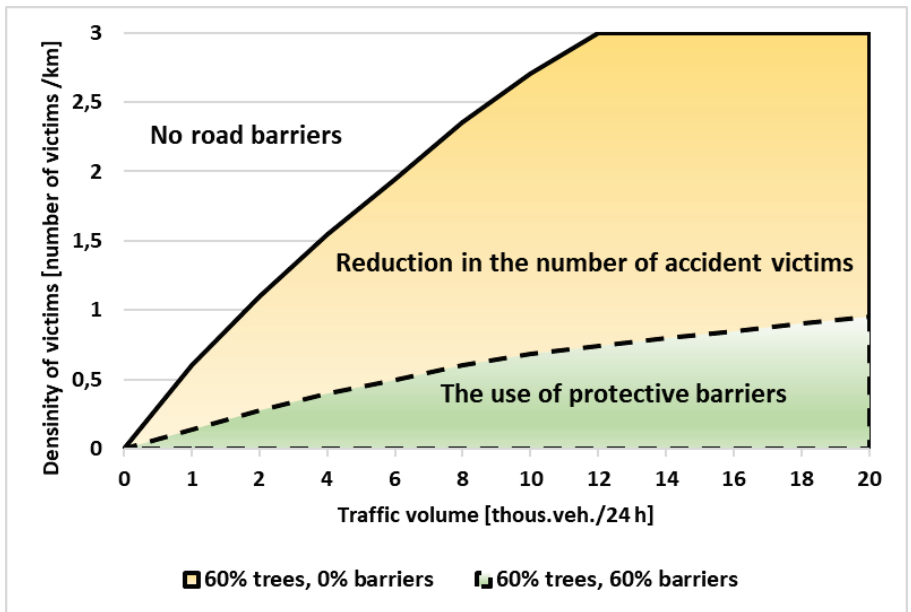

Rys. 5. Gęstość ofiar GOF w zależności od odległości drzew od krawędzi jezdni i udziału procentowego barier 


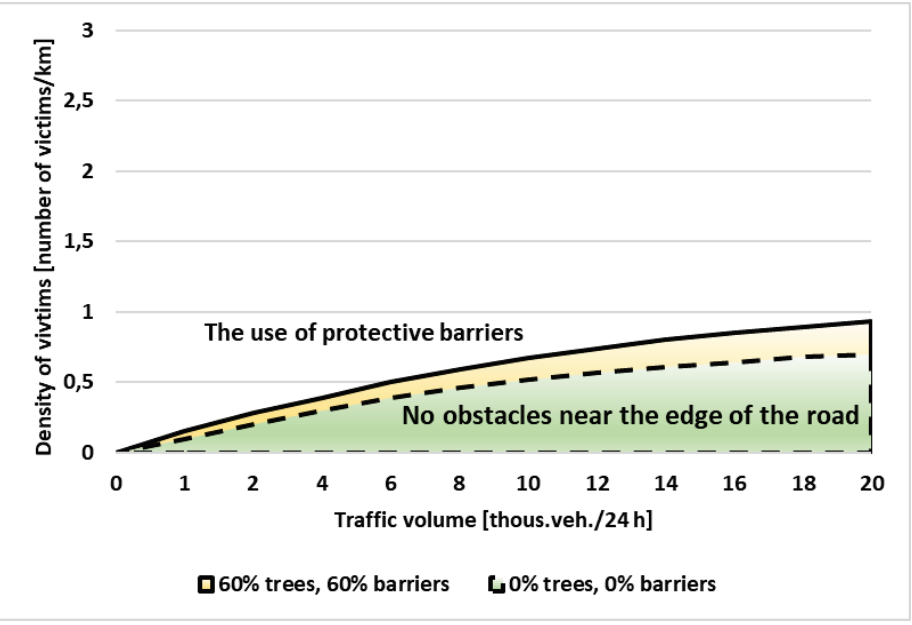

Rys. 6. Gęstość ofiar GOF w zależności od występowania barier ochronnych

\section{Podsumowanie i kierunki dalszych prac}

$\mathrm{Na}$ podstawie dotychczasowych prac autorów w zakresie zarządzania bezpieczeństwem infrastruktury drogowej, ze szczególnym uwzględnieniem otoczenia dróg, można sformułować następujące wnioski:

1. Zarządzanie bezpieczeństwem ruchu drogowego jest procesem bardzo złożonym, musi uwzględniać znaczną liczbę niewiadomych oraz zjawisk losowych. W związku z tym wymaga stosowania nowoczesnych narzędzi, umożliwiających identyfikację źródeł zagrożeń i samych zagrożeń.

2. Elementy infrastruktury drogowej należą do grupy czynników w znacznym stopniu odpowiedzialnych za powstawanie wypadków (jednak ich udział procentowy jest mniejszy niż czynników ludzkich - zachowania, błędy użytkowników ruchu drogowego) i jednocześnie czynniki infrastrukturalne dominują pod względem wpływu na konsekwencje wypadków z udziałem pojedynczego pojazdu (wypadnięcia, wywrócenia pojazdu, uderzenia w element otoczenia drogi).

3. Dominującymi czynnikami infrastrukturalnymi odpowiedzialnymi za konsekwencje wypadków drogowych z udziałem jednego pojazdu są te związane $\mathrm{z}$ otoczeniem dróg, co w znacznym stopniu wynika $\mathrm{z}$ braku odpowiednich regulacji i przepisów w tym zakresie. Konieczne jest opracowanie odpowiednich zasad porządkujących proces projektowania i utrzymania sieci drogowej. Blisko $20 \%$ wszystkich ofiar śmiertelnych na polskich drogach to konsekwencje wypadnięcia pojazdu z jezdni. 
4. Koniecznie jest budowanie i rozwijanie modeli określających wpływ czynników na miary bezpieczeństwa ruchu drogowego, co pozwoli wprowadzać odpowiednie zmiany $\mathrm{w}$ przepisach $\mathrm{w}$ zakresie projektowania i utrzymania infrastruktury drogowej.

W związku z powyższym, kierunki kolejnych badań w zakresie zarządzania bezpieczeństwem infrastruktury drogowej to:

- rozwój narzędzi do zbierania danych drogowych - automatyzacja procesu,

- uzupełnienie baz danych o kolejne parametry (np. krętość i falistość) odcinków drogowych),

- opracowanie metody klasyfikacji zagrożeń generowanych przez infrastrukturę drogową i jej otoczenie,

- budowa narzędzi umożliwiających zmiany w przepisach projektowych i utrzymaniowych, ze szczególnym uwzględnieniem otoczenia dróg (warunki techniczne dla dróg, wytyczne stosowania barier ochronnych itp.).

\section{Literatura}

1. Cova T.J., Conger S.: Transportation Hazards. Transp. Eng. Handb., No. 801, 2003.

2. Treat JR et al.: Tri-Level Study of the Causes of Traffic Accidents. Res. Rep. Compil. by Inst. Res. Public Saf. to US Separtment Transp. Washingt. DC, 1979.

3. Vogel L., Bester C.J.: A relationship between accident types and causes. Proc. 24th South. African Transp. Conf., 2005.

4. PIARC: Road accident investigation guidelines for road engineers. 2007.

5. The Institution of Engineering and Technology: Glossary of Safety Terminology. No. $00,2017$.

6. Jamroz K.: Method of risk management in road engineering. Politechnika Gdańska, 2011.

7. Ulbig E., Hertel R., Böl G.-F.: Evaluation of Communication on the Differences between "Risk" and "Hazard" Project implementation. 2010.

8. Lofstedt R.E.: Risk vs. Hazard how to regulate. Ejrr, Vol. 2, 2011.

9. WHO: Global Status Report on Road Safety 2015.

10. Budzyński M., Jamroz K., Jeliński Ł.: Assessment of road restraint systems in Polish conditions. Journal of KONBiN, No. 45, 2018, DOI 10.2478/jok-2018-0017.

11. Budzyński M., Jamroz K.: Strategy to reduce the number and consequences of run-offroad. Drogownictwo, Vol. 64, no. 4-5, 2009.

12. Abdel-Rahim A., Sonnen J.: Potential Safety Effects of Lane Width and Shoulder Width on Two-Lane Rural State Highways in Idaho. 2012.

13. Hallmark T.J., Qiu S.L., Pawlovitch Y., McDonald M.: Assessing the safety impacts of paved shoulders. J. Transp. Saf. Secur., 2013. 
14. Zegeer C.V, Council F.M.: Safety relationships associated with cross-sectional roadway elements. Transp. Res. Rec., 1995.

15. Aashto: Roadside Design Guide. 2011.

16. Saleh P., Philippe N., La Torre F., Helfert M.: A Guidance Document for the Implementation of the CEDR Forgiving Roadsides report. Natl. Roads Auth., Vol. 12, No. 16, 2013.

17. Park J., Abdel-Aty M., Lee C., Exploration and comparison of crash modification factors for multiple treatments on rural multilane roadways. Accid. Anal. Prev., Vol. 70, Sep. 2014.

18. Stamatiadis N., Pigman J., Sacksteder J., Ruff W., Lord D.: Impact of Shoulder Width and Median Width on Safety. NCHRP Rep. 633, 2009.

19. Jurewicz C., Pyta V.: Effect of clear zone widths on run-off-road crash outcomes. Australas. Road Saf. Res. Polic. Educ. Conf., No. September, 2010.

20. Van Petegem J.W.H., Wegman F.: Analyzing road design risk factors for run-off-road crashes in the Netherlands with crash prediction models. J. Safety Res., Vol. 49, no. February, 2014.

21. Park J., Abdel-Aty M., Assessing the safety effects of multiple roadside treatments using parametric and nonparametric approaches. Accid. Anal. Prev., Vol. 83, Oct. 2015.

22. Tingvall C., Haworth N.: Vision Zero-An ethical approach to safety and mobility. In: 6th ITE International Confer ence Road Safety \& Traffic Enforcement: Beyond 2000, Melbourne, 6-7 September 1999, 2000,

23. Budzyński M., Jamroz K., Kustra W.: Road safety inspection as a tool for road safety management-the polish experience. Journal of KONBiN, No. 42, 2017, DOI 10.1515/jok-2017-0017. 